\title{
Effects The Constitutional Court Decision Allowing Marriage Agreement After Marriage (Constitutional Court Decision No. 69 / PUU-XIII / 2015)
}

\begin{abstract}
Kevin Hanif Hakim ${ }^{1}$ and Akhmad Khisni ${ }^{2}$
Abstract. At first the marriage law stipulated in the Civil Law Act (Civil Code) and subsequent regulations related to marriage and even then dealt with separately by Act No. 1 of 1974 on Marriage. On October 272016 the Constitutional Court (MK) through its Decision No. 69 / PUU-XIII / 2015 gives constitutional interpretation of Article 29 of Act No. 1 of 1974 on Marriage which basically says that the marriage contract can be carried out during the marriage bond. Therefore, the object of the author's thesis writing is a result of the law of the Constitutional Court decision that allows marriage after marriage. And the formulation of the problem in this paper are the implications of the procedure / mechanism of making the marriage contract and the legal consequences of the status of the property as well as third parties who feel aggrieved over the agreement. Methods used by the authors te is normative research method. So as to obtain results that due to the Constitutional Court's decision that allows the marriage contract after marriage alter the legal mechanism of making the marriage contract that can now be created during the marriage bond takes place by the Notary without preceded by the determination of the competent court and the legal consequences of making the marriage contract after the wedding on the status of property together with the inherent (closely related) to the time of entry into force of the agreement and binding on third parties.
\end{abstract}

Keywords: Notary; Marriage Agreement; the Constitutional Court Decision

\section{Introduction}

Marriage is a bond physically and mentally between a man with a woman as husband and wife with the aim of forming a family (household) who are happy and everlasting based on God, while marriage according to Islamic law is marriage, the covenant is very strong or mitsaqan ghalizhaan to obey God's commands that the application is worship. The substance contained in the law of marriage is obeying the command of Allah and His Messenger that creates a home life that bring benefit both to the perpetrator's own marriage, children derivatives, relatives and the community.

Definition of marriage under Article 1 of Act No. 1 of 1974 which reads Marriage About Marriage is a bond between a man physically and mentally with a woman as husband and wife with the aim of forming a family (household) who are happy and everlasting based on God

In Indonesia regulation concerning plural marriages arranged such case is influenced by the customs of Indonesian society, each of which have different areas and are also influenced by various religious teachings, such as Hinduism, Buddhism, Christianity, Catholicism and Islam. The existence of a variety of influences in the community has

1 Students Master of Notary Faculty of Law UNISSULA, Semarang E-mail: kevinhanif02@gmail.com

2 Lecturer of Faculty of Law UNISSULLA. 
led to numerous rules governing marital problems, so the consequences on the way of life of family, kinship, and the richness of a person in public life. ${ }^{3}$

Covenant marriage is known in the Civil Code and Act No. 1 of 1974 About Marriage is an agreement made by a prospective husband and wife before Notary stating that they have agreed to make the separation on their property each in their marriage later, then after the treaty better then all the property acquired before or during marriage in the future is and remains the property rights of their own, as well as the lending of each party's right teresebut remain the rights and responsibilities of each the parties have the accounts payable. This is in accordance with the provisions of Article 139 of the Civil Code which states that "the covenant of marriage, both prospective spouses are entitled to set up some deviations from the regulations of Law about unity wealth, as long as the agreement does not violate the ethics of good or order public and Similarly ignored origin of all conditions set out below ". This means that the marriage agreement is an agreement on arrangements for the spouses of property acquired both before and during their marriage took place, which is a deviation is justified by the law of the principle or the pattern established by the Act. Based on the above background the authors are interested to do the writing thesis with the title: "Effects The Constitutional Court Decision Allowing Marriage Agreement After Marriage". With Problem Formulation 1. How implications Constitutional Court Decision No. 69 / PUUXIII / 2015 against the deed marriage agreement after mating Notary? 2. What is the legal effect of the marriage covenant deed that created the Notary before and after the Constitutional Court Decision No. 69 / PUU-XIII / 2015?

\section{Research method}

In this paper the authors use the method of normative juridical research. Normative juridical means a deductive study began an analysis of the provisions in the legislation that governs against the above problems.

Specifications research is descriptive analysis, which describes the problem and then analyze the existing problems through data that has been collected, processed, and prepared based on the theories used. This study is expected to obtain a clear picture of understanding, a detailed and systematic way of analyzing data to solve the problem in accordance with the provisions of applicable law.

The necessary data can be obtained and derived from: primary legal materials derived from the legislation include: The Book of Civil Law, Act No. 30 of 2004 concerning Notary, Act No. 2 of 2014 on the Amendment Act Act No. 30 of 2004 concerning Notary, Act No. 1 of 1974 About Marriage, Compilation of Islamic Law, Constitutional Court Decision No. 69 / PUU-XIII / 2015

The data has been collected, studied, and analyzed based on the facts of a general nature subsequently drawn conclusions that are special to reach the answers to the issues discussed. The data obtained in writing is what is expected to be able to obtain a clear picture of the underlying problems and can be used to draw conclusions in this paper. 3Hilaman Hadikusuma, 2010, Hukum Perkawinan Indonesia, Menurut Perundangan Hukum
Adat dan Hukum Agama, Bandung, CV. Mandar Maju, p. 8. 


\section{Discussion}

\subsection{Implications of Constitutional Court Decision No. 69 / PUU-XIII / 2015 against the marriage covenant deed after mating Notary}

The provisions concerning the manufacture of the marriage covenant are set out in Act No. 1 of 1974 on Marriage does not regulate the manufacture of a marriage agreement after the wedding was held. The provisions in Article 29 of the Act that essentially only regulates the marriage contract that can be made on or before the marriage took place, but the phenomenon of development in society (practice) can be found covenant marriage made at the time of the bond of marriage lasts that for certain reasons between the couple recently made a covenant marriage, while such things can be justified by the law on the grounds that the treaty so it must be preceded by request to the competent court in order to obtain a determination of the judge, as the court ruling.

Furthermore, after receiving the court ruling parties (husband and wife) can then make a deed of covenant marriage after mating presented to a Notary. Because based on Article 15 (1) of Act No. 2 of 2014 on the Amendment of Act No. 30 of 2004 concerning Notary mention that the Notary authorized to make the authentic act on all deeds, agreements, and provisions required by legislation and / or desired by the stakeholders to be stated in an authentic deed, guaranteeing the creation date of the deed, saving certificates, giving grosse, copy, and official copies, all of it throughout the making of the deed it not also be assigned or excluded to other officials or others defined by the Act.

Therefore, when associated between that article (authority Notary) with the marriage contract after mating has to first get the determination of the court, it means that even if the treaty so it was carried out when the marriage took place by first getting the determination of the court but does not reduce the essence Notary of authority as a public official in deed the marital agreement.

Then instead of the deed of agreement has been made in the presence of the Notary registered with the agencies that are authorized by legislation to listing it is the Department of Population and Civil Registration or Religious Affairs Office (KUA) according to legal subject. If the deed of covenant marriages were then not registered then by itself is not legally binding for third parties. ${ }^{4}$

But after the release of the decision of the Constitutional Court Number 69 / PUU XIII / 2015 dated March 21, 2016 the changes were related to the manufacture of the marriage contract, the decision on the request for an Indonesian citizen who perform mixed marriages, who enter into marriage without making the marriage contract. As time goes tersebutpun couple intends to buy a house / apartment, but because of the regulations that apply in the context of national land law, namely the provisions on BAL adopts the principle of nationality, which means that any citizen only yangbiasmemiliki land rights in Indonesia. Therefore, then a couple of mixed marriages are applying for constitutional review (testing constitutional) to the Constitutional Court because have felt aggrieved by the existence of Article 21 paragraph (1), and paragraph (3), Article 36 paragraph (1) of the BAL, Article 29 paragraph ( 1), paragraph (3), (4), paragraph and Article 35 paragraph (1) of the Marriage Act.

\footnotetext{
${ }^{4}$ http://alwesius.blogspot.co.id/2016/11/pembuatan-perjanjian-perkawinan-pasca.html,
} 
Furthermore, upon the request so that the Court argued in its legal considerations mentioned that: Strictly speaking, the provisions of which there are currently only arrange the marriage covenant made before or during the marriage took place, when in reality there is the phenomenon of husband and wife who for some reason just feel the need to make arrangements to marry during the marriage bond. During this time in accordance with Article 29 of Act No. 1 of 1974 the treaty so it should be held before the marriage took place and must be placed in a notarial deed. Marital Agreement comes into force between husband and wife since the marriage took place. The contents are arranged in the Agreement of marriage depends on the agreement the parties prospective husband and wife, as long as not contrary to law, religion, and decency or morality, while on the shape and content of the marriage contract, both parties are given the freedom or independence large measuring.

Then after Constitutional Court decision, are now husband and wife that time or before the marriage took place did not make the marriage contract, if the parties (husband and wife) wants to make the marriage contract throughout the marriage, the parties do not have to ask for a court warrant for the purposes of making a marriage contract such as it has several times happened, the parties who want to make the marriage contract can be made directly to the notaries who then subsequently submitted to the Department of Population and Civil registration or Religious Affairs Office (KUA) to the recording of the deed of covenant marriage.

\subsection{The legal consequences of the marriage covenant deed that created the Notary before and after the Constitutional Court Decision No. 69 / PUU- XIII / 2015}

The legal consequences of the marriage covenant deed after mating before and after the Constitutional Court Decision No. 69 / PUU-XIII / 2015 on the status of joint property and third party Notary as follows

- The legal consequences of the marriage covenant deed after mating before the Constitutional Court Decision No. 69 / PUU-XIII / 2015 is based on the establishment of the East Jakarta District Court on the status of joint property and third parties, namely

- Any change in the status of conjugal property, originally a joint property, ${ }^{5}$ be the personal property of each conjugal accordance with the agreed and is based in the determination of the District Court;

- Marriage agreement made after mating based determination of the East Jakarta District Court valid and binding on both parties to create and bind a third party along Determination of making the marriage contract after mating does not harm third parties.

- The legal consequences of the marriage covenant deed after mating after the Constitutional Court Decision No. 69 / PUU-XIII / 2015 on the status of joint property and third parties, namely:

- The legal consequences of making the marriage contract after the wedding on the status of joint property inherent (closely related) to the time of entry into force of the agreement. Based on the Constitutional Court ruling marital agreement entered into force since the marriage took place, unless otherwise

${ }^{5}$ http://jurnal.unissula.ac.id/index.php/jhku/article/view/1849/1393 
stipulated in the Marriage Covenant. ${ }^{6}$ That means that if the parties could not determine when the marriage agreement comes into force then by law the marriage agreement comes into force since the marriage took place. Thus the legal effects of the status of community property made a covenant marriage after mating, which began berlau since the marriage took place, followed by the status of community property into separate if desired both parties in the agreement, as well as to assets to be acquired in the future remain the property of their party, without having to obtain a court warrant, the separation of property.

- The legal consequences of making the marriage contract by the Constitutional Court Decision applicable and binding on third parties. Making the marriage contract so it should not harm third parties. ${ }^{7}$ for the manufacture of the marriage covenant marriage lasted throughout the legal consequences of the change in the legal status of property contained or acquired in the marriage.

\section{Closing}

\subsection{Conclusion}

- Implications of Constitutional Court Decision No. 69 / PUU-XIII / 2015 against the marriage covenant deed after mating before a Notary change marriage covenant making legal mechanisms which can now be created during the marriage bond takes place by the Notary without preceded by the establishment of a competent court. Initially the provisions of Articles of the Marriage Law, although only regulates the marriage contract that can be made on or before the marriage took place, but a phenomenon that occurs in the community can be found covenant marriage made at the time of the marriage lasts that for certain reasons between husband and wife the new make marriage agreement, which must be preceded by request to the competent court in order to obtain a determination of the judge, who then later it can make a Notary deed of covenant marriage after mating to be determined by the court.

- The legal consequences of the marriage covenant deed after mating before and after the Constitutional Court Decision No. 69 / PUU-XIII / 2015 on the status of joint property and third party Notary.

\subsection{Suggestion}

Based on the conclusions outlined above, the authors propose the following suggestions:

- The government in this case to decide immediately relevant technical regulations are legal mechanisms of making the marriage contract by the Constitutional Court ruling that gave constitutional interpretation stating marriage agreement can also be made during the ongoing marriage bond that also bind third parties.

- In establishing the technical regulations related to the legal mechanism of making

6 http://jurnal.unissula.ac.id/index.php/ua/article/view/2456

7 Farida Novita Sari dan Umar Ma'ruf, 'Perlindungan Hukum Terhadap Harta Dalam Akta Perjanjian Kawin Yang Dibuat Oleh Notaris Bagi Warga Negara Indonesia Yang Beragama Islam" in Jurnal Akta Vol 4, No 2 (2017), http://jurnal.unissula.ac.id/index.php/akta/article/view/1796 
the marriage contract by the Constitutional Court ruling government should accommodate into the regulation of the ministers associated with the stages of the formal procedure of manufacture until the registration or recording of the deed of the agreement in order to legality a marriage contract after mating that legally can bind and do not harm third parties.

\section{Bibliography}

[1] Hilaman Hadikusuma, Hukum Perkawinan Indonesia, Menurut Perundangan Hukum Adat dan Hukum Agama, (Bandung : CV. Mandar Maju, 2010)

[2] Ronny Hanitijo Soemantri, Metodologi Penelitian Hukum dan Jurimetri, Ghalia Indonesia, Jakarta, 2009

[3] http://alwesius.blogspot.co.id/2016/11/pembuatan-perjanjian-perkawinan-pasca.html,

[4] http://jurnal.unissula.ac.id/index.php/ihku/article/view/1849/1393

[5] http://jurnal.unissula.ac.id/index.php/ua/article/view/2456

[6] http://jurnal.unissula.ac.id/index.php/akta/article/view/1796 